\title{
A review of vitamin A equivalency of $\beta$-carotene in various food matrices for human consumption
}

\author{
Carolien A. Van Loo-Bouwman ${ }^{1 *}$, Ton H. J. Naber ${ }^{1,2}$ and Gertjan Schaafsma ${ }^{3}$ \\ ${ }^{1}$ Department of Gastroenterology and Hepatology, Radboud University Nijmegen Medical Centre, Geert Grooteplein 8, \\ 6525 GA Nijmegen, The Netherlands \\ ${ }^{2}$ Department of Internal Medicine and Gastroenterology, Tergooi, Van Riebeeckweg 212, 1213 XZ, Hilversum, \\ The Netherlands \\ ${ }^{3}$ Schaafsma Advisory Services in Food, Health and Safety, Rembrandtlaan 12, 3925 VD, Scherpenzeel, The Netherlands \\ (Submitted 10 June 2013 - Final revision received 9 January 2014 - Accepted 10 January 2014 - First published online 11 February 2014)
}

\section{Abstract}

Vitamin A equivalency of $\beta$-carotene (VEB) is defined as the amount of ingested $\beta$-carotene in $\mu \mathrm{g}$ that is absorbed and converted into $1 \mu \mathrm{g}$ retinol (vitamin A) in the human body. The objective of the present review was to discuss the different estimates for VEB in various types of dietary food matrices. Different methods are discussed such as mass balance, dose-response and isotopic labelling. The VEB is currently estimated by the US Institute of Medicine (IOM) as 12:1 in a mixed diet and 2:1 in oil. For humans consuming $\beta$-carotene dissolved in oil, a VEB between 2:1 and 4:1 is feasible. A VEB of approximately 4:1 is applicable for biofortified cassava, yellow maize and Golden Rice, which are specially bred for human consumption in developing countries. We propose a range of 9:1-16:1 for VEB in a mixed diet that encompasses the IOM VEB of 12:1 and is realistic for a Western diet under Western conditions. For a 'prudent' (i.e. non-Western) diet including a variety of commonly consumed vegetables, a VEB could range from 9:1 to 28:1 in a mixed diet.

Key words: Vitamin A equivalency: $\beta$-Carotene: Bioconversion: Human studies

Vitamin A equivalency of $\beta$-carotene (VEB) is defined as the amount of ingested $\beta$-carotene in $\mu \mathrm{g}$ that is absorbed and converted into $1 \mu \mathrm{g}$ retinol (vitamin A) in the human body. A certain amount of the ingested $\beta$-carotene is excreted in the faeces and the remaining part is absorbed, but not all of the absorbed $\beta$-carotene will be converted into retinol and enter the lymph, blood and finally the liver and other tissues.

Vitamin A can be obtained from animal-derived foods as preformed vitamin $\mathrm{A}$, or from vegetables and fruits as provitamin A carotenoids, mainly $\beta$-carotene, $\alpha$-carotene and $\beta$-cryptoxanthin. In the Western diet, about 20 to $34 \%$ of the habitual intake of vitamin A originates from provitamin A carotenoids $^{(1-3)}$. In contrast, the majority of individuals in developing countries require $>70 \%$ of provitamin A carotenoids in the $\operatorname{diet}^{(4)}$. The effect of food matrices of vegetables and fruits in which $\beta$-carotene is incorporated has been found to exert a major influence on measured VEB.

The objective of the present review was to discuss the different estimates for VEB in various types of dietary food matrices.
The question is which VEB should be used for humans in general good health.

For this purpose, first, the currently used VEB are described. Second, a brief overview of the main influencing factors on the assessment of VEB is given. Third, the habitual daily intake of dietary vitamin $\mathrm{A}$ and $\beta$-carotene in humans is described. Fourth, different methods for estimating VEB are discussed to evaluate the reliability of the different studies. The studies are grouped by the different types of dietary food matrices in which $\beta$-carotene is incorporated, which are the oil matrix, the complex mixed diet matrix with various vegetables and fruits and the single vegetable or fruit matrix.

\section{Currently used vitamin A equivalency of $\beta$-carotene}

Currently, two estimates of VEB for the oil matrix and two estimates of VEB in the mixed diet matrix are in use. In the 1967 recommendation of the FAO/WHO, the estimated VEB in the oil matrix was $3 \cdot 3: 1$, so $3 \cdot 3 \mu \mathrm{g} \beta$-carotene dissolved in oil would be required in the diet to produce $1 \mu \mathrm{g}$ retinol in the

Abbreviations: BCMO1, $\beta, \beta$-carotene $15,15^{\prime}$-mono-oxygenase; TRL, TAG-rich lipoprotein; VEB, vitamin A equivalency of $\beta$-carotene.

*Corresponding author: C. A. Van Loo-Bouwman, email Carolien.VanLooBouwman@hotmail.com

† Present address: Sparrenhout 10, 3991 PT Houten, The Netherlands. 
human body ${ }^{(5)}$. According to the 1967 and 1988 recommendations of the $\mathrm{FAO} / \mathrm{WHO}^{(2,5)}$, the VEB for a mixed vegetable diet was estimated to be $6: 1$ and for other provitamin A carotenoids as 12:1. This VEB of $6: 1$ for a mixed diet is referred to as the retinol equivalents and is used in many food composition tables. The revised food composition tables have used the retinol activity equivalents, which is a VEB of 12:1 for a mixed diet and 24:1 for other provitamin A carotenoids ${ }^{(1)}$. The term 'retinol activity equivalents' was introduced by the US Institute of Medicine (IOM) ${ }^{(1)}$. The IOM adopted a two-step process: first, examining VEB in oil, and then examining the absorption of $\beta$-carotene in vegetable foods relative to that of $\beta$-carotene dissolved in oil. The revised VEB of 12:1 for a mixed plant diet was calculated from the products of $1 / 2$ (the intestinal conversion factor of $\beta$-carotene in oil) and $1 / 6$ (the relative absorption of $\beta$-carotene in a mixed plant diet). The intestinal conversion factor of $\beta$-carotene in oil should be interpreted as $2 \mu \mathrm{g}$ absorbed $\beta$-carotene in the enterocyte that is equivalent to $1 \mu \mathrm{g}$ retinol in the human body, as has been reported in classical studies ${ }^{(6,7)}$.

In the 2004 report of the $\mathrm{FAO} / \mathrm{WHO}$, the committee retained the VEB of 6:1 for a mixed diet and emphasised that the conditions that prevent carotenoids from entering enterocytes, such as the food matrix, are more significant than previously thought, and that more data might support an even lower VEB for a mixed $\operatorname{diet}^{(4)}$

\section{Main influencing factors on the assessment of vitamin A equivalency of $\beta$-carotene}

There are many diet-related and host-related factors that may affect VEB. The main diet-related factors that influence VEB in humans are the food matrix in which $\beta$-carotene is incorporated, the amount ingested and the habitual diet type ${ }^{(8,9)}$. The rupture of the food matrix by heating and homogenising promotes the release of $\beta$-carotene from plant cells before and during digestion, and therefore it facilitates solubilisation into mixed lipid micelles in the lumen and cellular uptake by intestinal mucosal cells ${ }^{(10)}$. Cell wall structure in fruits is usually weaker than that in leaves, and therefore VEB for fruits deviates from that for vegetables ${ }^{(11)}$.

VEB may be regarded as constant as long as the consumption of $\beta$-carotene is within physiological ranges and the host is in good health. With pharmaceutical doses of $\beta$-carotene, serum $\beta$-carotene levels increase, and VEB can decrease when an oral dose of $\beta$-carotene increases ${ }^{(2,12,13)}$. The habitual diet type determines the composition of the diet, and therefore various nutrient-to-nutrient interactions affect to a larger extent the absorption of $\beta$-carotene. For example, $\beta$-carotene absorption can be inhibited by lutein ${ }^{(14,15)}$, when a minimum amount of about $5 \mathrm{~g}$ dietary fat is consumed simultaneously in a meal to ensure intestinal $\beta$-carotene uptake ${ }^{(16)}$. Also, absorption of $\beta$-carotene is reduced when dietary fibre content increases. Fibre interacts with bile acids, resulting in decreased absorption of fats and fat-soluble substances such as $\beta$-carotene ${ }^{(17)}$.

Host-related factors, such as age, pregnancy, health status, immune status and treatment for worms and diarrhoea, can also affect $\mathrm{VEB}^{(18,19)}$. Intestinal helminthic infections are associated with malnutrition, and their effects are possibly mediated through impaired fat absorption and reduced vitamin absorption, particularly vitamin $\mathrm{A}^{(18,19)}$. Micronutrient malabsorption detected during intestinal parasitic infections is not easily explained or investigated, and may be caused by injury to the intestinal mucosa without invasion, mucosal invasion by parasites or bacterial overgrowth in the upper small bowel ${ }^{(20)}$. These host-related factors could have more influence on populations in developing countries than on populations in Western countries, where public health care is well organised and, in general, persons are in good health. Another host-related factor is the recently described polymorphism in the $\beta, \beta$-carotene $15,15^{\prime}$-mono-oxygenase (BCMO1) gene coding for the enzyme that cleaves $\beta$-carotene ${ }^{(21,22)}$. Studies have identified low responders who showed little or no response to plasma $\beta$-carotene concentration after a labelled dose of $\beta$-carotene ${ }^{(23-25)}$. The large inter-individual differences for estimates of VEB might be due to reduced enzymatic activity as a consequence of down-regulated activity of BCMO1 or polymorphisms in the BCMO1 gene. However, in none of the studies discussed below were the genetic polymorphisms analysed, as the importance of BCMO1 was only recently realised; therefore, VEB may be more efficient than currently proposed.

The currently used VEB in a mixed diet and in oil are applicable only for individuals in general good health.

\section{Habitual daily intake of vitamin $A$ and $\beta$-carotene in human subjects}

A Western type of diet, consumed by most people in developed countries, is relatively high in animal-derived foods (meat and dairy products), processed foods, fats and oils, and refined grains but relatively low in dietary fibres (vegetables, fruits and whole grains) ${ }^{(26,27)}$. Milk and dairy products contribute 15 to $20 \%$ to total vitamin A intake. In the Western diet, about 66 to $80 \%$ of the habitual intake for vitamin A is preformed vitamin $\mathrm{A}$ in the diet, and 20 to $34 \%$ of intake is from provitamin A carotenoids ${ }^{(1-3)}$. By assuming that at least $50 \%$ of provitamin A carotenoids are $\beta$-carotene, dietary $\beta$-carotene contributes for at least 10 to $17 \%$ in the Western diet to daily dietary vitamin A activity.

In contrast, the diet for most people living in developing countries contains only about 12 to $22 \%$ of preformed vitamin A, and consequently, they require 78 to $88 \%$ of provitamin $\mathrm{A}$ carotenoids in the $\operatorname{diet}^{(4)}$. By assuming that at least $50 \%$ of provitamin A carotenoids are $\beta$-carotene, dietary $\beta$-carotene contributes for at least 39 to $44 \%$ in the diet to daily dietary vitamin A activity in developing countries. Many people residing in developing countries consume the 'prudent' diet type, which is high in fresh fruits and vegetables and whole grains (e.g. rice, maize), and low in meat ${ }^{(26,27)}$. Overall, adults in the USA and Europe have a total vitamin A intake of 700-1000 $\mu \mathrm{g}$ retinol equivalents/d, and those in Southeast Asia and Africa have a total vitamin A intake of $400-800 \mu \mathrm{g}$ retinol equivalents/d, which is particularly low in animal sources $^{(4)}$. For populations that are highly dependent for 
their vitamin A status on the consumption of vegetables and fruits, it is important to have available the correct VEB values in various food matrices to be able to choose vegetables and fruits with the highest $\beta$-carotene amount and the highest VEB to maintain or increase their vitamin A status.

\section{Methods}

In the past decades, various methods have been used for determination of VEB. Over the years, the chemical analyses of blood, lymph and faeces have been optimised, resulting in higher recoveries of internal standards and better reproducibility within and between samples. Many studies have been performed by measuring serum or plasma $\beta$-carotene and retinol levels after a single meal (dose-response) or after a period of depletion and/or repletion. By measuring $\beta$-carotene levels in the faeces during a controlled diet, oral-faecal mass balance can be investigated. More recently, progress in the analysis of radio- and stable isotopes in blood has made possible the application of isotopic dilution methods. Extrinsic labelling involves mixing an exact dose of isotopically labelled $\beta$-carotene into a food source. The great advantage of using isotope-labelled $\beta$-carotene is that only relatively small physiological doses need to be used to follow metabolic pathways such as true absorption and conversion into retinol by discriminating between absorbed and endogenous $\beta$-carotene. Table 1 shows the major strengths and major limitations of the methods used to study VEB in human subjects as discussed below.

\section{Depletion-repletion method}

Studies of depletion and repletion responses using a dark adaptation endpoint have been published by Hume \& Krebs ${ }^{(28)}$ and Sauberlich et al. $^{(29)}$. During consumption of a vitamin Adeficient diet, subjects developed impaired dark adaptation (depletion phase). In the repletion phase of the study, the amount of retinol or $\beta$-carotene that was required to reverse the impaired dark adaptation was estimated. Such experiments are not allowed anymore because of medical ethical reasons. Moreover, the method provides only crude estimates because stepwise increased doses of $\beta$-carotene are tested. However, these experiments were the first attempts to assess VEB in oil, and they still influence the current recommendations.

\section{Animal models}

Animal models may be very useful for studying qualitative problems, but they have limited use for studying quantitative processes that represent the situation in human subjects. There is no validated way to extrapolate animal data to physiological conditions in human subjects. Monkeys, gerbils and preruminant calves convert $\beta$-carotene into vitamin $\mathrm{A}$ with an efficiency comparable to that of humans. However, in humans, $\beta$-carotene is mainly transported in the LDL fraction and many animals, such as ferrets and calves, have a retinyl ester metabolism different from that in humans, resulting in high levels of fasting plasma retinyl esters. Mice, rats, ferrets and chickens efficiently convert $\beta$-carotene into vitamin $\mathrm{A}$, but absorb $\beta$-carotene intact only when it is provided in the diet at levels much higher than is considered physiological for humans. Not one animal model completely mimics human absorption and metabolism of $\beta$-carotene and therefore cannot be used to study the VEB in human subjects ${ }^{(30-32)}$.

\section{In vitro models}

Results from in vitro models cannot be translated to the human situation, but can provide some predictions. For example, the available time for food processing can be influenced by various food matrices and different levels of enzymes and $\mathrm{pH}$ simulating infant or adult situations, as these factors influence the transit time and competition for absorption ${ }^{(8,9)}$. An in vitro gastrointestinal model can precisely measure the bioaccessible fraction, which is available for absorption by measuring $\beta$-carotene in mixed micelles in different prepared meals of vegetable foods. Measurements in isolated human intestinal epithelial cells provide estimates of the conversion of $\beta$-carotene into retinol under various conditions.

\section{Mass balance method}

In the mass balance method, the apparent $\beta$-carotene absorption is estimated as the difference between controlled

Table 1. Overview of the methods used to study vitamin A equivalency of $\beta$-carotene in human subjects with their major strengths and major limitations

\begin{tabular}{|c|c|c|}
\hline Methods & Strength & Limitation \\
\hline Depletion-repletion & Crude estimates by stepwise increased doses & Ethical considerations due to depletion \\
\hline Mass balance & $\begin{array}{l}\text { Feasible with a controlled diet and } \\
\text { faecal collection }\end{array}$ & Sensitive to underestimation and overestimation \\
\hline Dose-response & $\begin{array}{l}\text { Controlled dose measured in a relatively } \\
\text { short time }\end{array}$ & $\begin{array}{l}\text { Length of time for increased levels } \\
\text { and for AUC calculation }\end{array}$ \\
\hline Retinyl ester response & $\begin{array}{l}\text { Measurement of newly absorbed and converted } \\
\beta \text {-carotene }\end{array}$ & Inter-individual variation in chylomicron kinetics \\
\hline Retinyl ester response with isotopes & Control for chylomicron kinetics & Sensitivity of detection \\
\hline Extrinsic radioisotopic labelling & Limited number of subjects & Potential radiation damage \\
\hline Extrinsic stable isotope labelling & $\begin{array}{l}\text { Precise measurement of the isotopic ratio } \\
\text { of labelled:unlabelled retinol }\end{array}$ & $\begin{array}{l}\text { Assumption of the same kinetics of labelled } \\
\text { and unlabelled } \beta \text {-carotene and retinol }\end{array}$ \\
\hline Intrinsic isotopic labelling & $\begin{array}{l}\text { Same kinetics of labelled and unlabelled } \\
\beta \text {-carotene in plant sources }\end{array}$ & $\begin{array}{l}\text { Availability of these specially produced dietary } \\
\text { plant sources }\end{array}$ \\
\hline
\end{tabular}


$\beta$-carotene intake and faecal $\beta$-carotene excretion over a period of time. On the one hand, data obtained from the oral-faecal mass balance method might be overestimated because of (bacterial) degradation of carotenoids in the gut and incomplete faecal collection. On the other hand, endogenously secreted carotenoids may be excreted in the faeces, thus leading to underestimation of the absorption of dietary carotenoids. Faecal collection studies in ileostomy subjects have the advantage of excluding the possible effect of bacterial degradation or even synthesis of $\beta$-carotene in the colon, resulting in less overestimation of absorption in human subjects with an intact gut ${ }^{(33-37)}$. In spite of these limitations, oral-faecal mass balance studies may yield reasonable measurements of apparent intestinal $\beta$-carotene absorption. Together with the assumption of the FAO/WHO and IOM that half the absorbed amount of $\beta$-carotene in the intestine is converted into retinol, an acceptable estimate of VEB can be obtained using the mass balance method ${ }^{(33)}$.

\section{Dose-response method}

Many dose-response studies have been conducted with $\beta$-carotene by measuring the blood level response over time after consuming a certain amount of $\beta$-carotene (for a review, see Swanson et ll $^{\left({ }^{(3)}\right)}$ ). The most commonly applied methods have included the measurement of the increase in serum or plasma $\beta$-carotene levels following chronic intervention, and the calculation of the AUC using the curves of total responses $v$. time following a single dose of $\beta$-carotene ${ }^{(39)}$. The concentration of $\beta$-carotene in serum or plasma represents a balance between intestinal absorption, breakdown, tissue uptake and release from body stores. The disadvantage of these studies is the homeostatic control of serum or plasma retinol concentrations. However, change from baseline serum or plasma $\beta$-carotene concentration can be useful as an endpoint to estimate the relative absorption of $\beta$-carotene in human subjects, provided such studies are sufficiently long to result in a new steady-state condition. Only dose-response studies with an (isotopic) reference dose can directly measure a VEB.

\section{Retinyl ester response method}

As the liver does not secrete retinyl esters, except when its storage capacity is saturated, newly absorbed and converted $\beta$-carotene can be measured by determining retinyl esters in chylomicrons. The advantage of the retinyl ester response method over the serum/plasma response method is that it accounts for intestinal conversion of $\beta$-carotene into retinyl esters. Consequently, it is theoretically possible to assess the VEB by measuring the retinyl ester response in postprandial blood. However, in practice, this is generally not feasible because of the low instantaneous concentration of chylomicron retinyl esters, the relatively low sensitivity of direct determination of retinyl ester concentration by HPLC, and the presence of large quantities of other lipids in extracted plasma or serum. In some studies, postprandial chylomicron $\beta$-carotene or retinyl ester response has been measured with a single oral dose of $\beta$-carotene $e^{(40-42)}$. Also, two earlier lymph recovery studies were carried out in subjects with lymph cannulation ${ }^{(6,7)}$.

Interpretation of postprandial response curves of $\beta$-carotene and retinol esters in TAG-rich lipoprotein (TRL) data is limited by the lack of means to control for inter-individual variations in in vivo chylomicron clearance kinetics or variations in chylomicron recovery during the preparation and analysis of TRL. Consequently, use of this approach is generally restricted to comparative (between-treatment) studies, because it does not directly measure the VEB.

\section{Retinyl ester response method with isotopes}

Edwards et al. ${ }^{(43,44)}$ adapted the TRL response model and co-administered $\left[{ }^{2} \mathrm{H}_{4}\right]$ retinyl acetate as an extrinsically isotope-labelled reference standard. This extrinsic reference dose controls for variations in chylomicron kinetics in vivo and for retinyl ester recovery during the preparation and analysis of TRL. The sensitivity and reproducibility of the detection of $\beta$-carotene in the plasma chylomicron fraction should be optimised before this approach can deliver reliable estimates of $\mathrm{VEB}^{(45)}$.

\section{Extrinsic radioisotopic labelling method}

The radioisotope tracer method requires a compartment model to interpret the increasing tracer curves after ingesting a single dose or constant infusion by assuming that the body is in endogenous constant steady state. Isotopic tracer techniques can provide accurate estimates of VEB with high precision, thus enabling studies with a limited number of subjects. The isotopic enrichment of labelled $\beta$-carotene in serum or plasma is corrected for the amount of labelled $\beta$-carotene consumed after some hours or days. By using isotope-labelled $\beta$-carotene, the measurement can distinguish between recently absorbed and endogenous $\beta$-carotene. Radioisotopes have been used only occasionally ${ }^{(6,7,46,47)}$ because of potential radiation damage.

\section{Extrinsic stable isotope labelling method}

In the past two decades, the availability of stable isotopelabelled compounds increased and, their analyses were improved. The use of stable isotopes in research is safe for human subjects and accepted by institutional review boards. The stable isotope tracer dilution method consists of administering an oral single or multiple doses, collection of a blood sample, measurement of the plasma or serum isotopic ratio of tracer:tracee (unlabelled vitamin A), and the use of a prediction equation for calculation of the bioavailability of $\beta$-carotene or VEB. Isotopic dilution techniques can also be used to estimate the total amount of vitamin A in the body, which has been described in the review of Furr et al. ${ }^{(48)}$.

Presently, over thirty studies have been conducted using stable isotope tracer techniques for studying the bioavailability of $\beta$-carotene and VEB in human subjects. Because of their design, some studies could only provide qualitative data, and 
some other studies were performed with a limited number of subjects. Since the early $1990 \mathrm{~s}$, it was possible to follow absorption and biokinetics of labelled $\beta$-carotene or retinol after a single dose ${ }^{(49-51)}$. Over 20 years ago, Parker et al. ${ }^{(49)}$ pointed out the necessity of stable isotope tracer methods for studying VEB in human subjects. The commonly used assumption is that the absorbed labelled $\beta$-carotene and retinyl palmitate are secreted and cleared with approximately the same kinetics as the unlabelled carotenoids and retinyl esters in the diet. Interpretation of data and mathematics from single-dose labelling studies are more complicated than those from multiple-dose labelling studies in which a plateau of isotopic enrichment is measured far above the threshold limit ${ }^{(45)}$

\section{Intrinsic isotopic labelling method}

Intrinsically labelled vegetables can be produced by irrigating with ${ }^{2} \mathrm{H}$-labelled water or by supplying ${ }^{13} \mathrm{CO}_{2}$ in a closed atmosphere $^{(52)}$. The advantage of the use of intrinsically labelled vegetables is that it is not necessary to assume that the labelled compound behaves in the same way as the unlabelled compound. To date, the following intrinsically isotope-labelled vegetables have been produced: biofortified yellow maize ${ }^{(53)}$; biofortified 'Golden Rice ${ }^{(54,55)}$; carrot $^{(56-58)}$; spinach $^{(54,57-59)}$; collard greens ${ }^{(59)}$; kale $^{(60,61)}$; tomato ${ }^{(62)}$. Because these specially produced vegetables are very expensive, few subjects could participate and only one simple single meal was measured. With this intrinsic labelling method, accurate data of VEB can be expected for specific vegetables and for human subjects with diverse nutritional status. However, data of VEB for a complex mixed diet with various vegetables and fruits are not yet available using the intrinsic labelling method.

\section{Summary of studies}

By comparing data from the aforementioned studies, the method and the three main factors that influence VEB in humans (the food matrix, the amount ingested and the habitual diet type) should be mentioned. The present review focuses on the influence of the food matrix on VEB and distinguishes the results by the different types of dietary food matrices of $\beta$-carotene, which are the oil matrix, the complex mixed diet matrix with various vegetables and fruits and the single vegetable or fruit matrix.

The majority of the data that the IOM reconsidered in 2001 were obtained from children and adults in developing countries with an inadequate nutritional status and their own habitual dietary patterns. The minority of the studies that IOM reviewed were obtained from subjects in developed countries with an adequate nutritional status, consuming a Western diet. Additional studies, especially those using stable isotopes, have been published since then (see Tables 2-4).

\section{Oil matrix: $\beta$-carotene dissolved in oil}

Overall, eighteen studies are presented in Table 2, of which four ${ }^{(28,29,63,64)}$ measured the VEB in oil with unlabelled $\beta$-carotene and fourteen ${ }^{(25,33,54,65-73)}$ with labelled $\beta$-carotene. Of these studies, two had a depletion-repletion study design $^{(28,29)}$. In the Sheffield experiment during the Second World War, Hume \& $\mathrm{Krebs}^{(28)}$ compared the amount of $\beta$-carotene with the amount of retinol required to reverse and prevent abnormal dark adaptation. Only two subjects achieved abnormal dark adaptation or correction of abnormal dark adaptation with $\beta$-carotene. Data for these two responding subjects suggested a VEB of 3·8:1 based on the observation that $390 \mu \mathrm{g}$ retinol or $1500 \mu \mathrm{g} \beta$-carotene reversed abnormal dark adaptation. Many years later, a study with six subjects was performed with a validated method to confirm impaired visual function in response to vitamin A depletion ${ }^{(29)}$. The VEB was determined to be $2: 1$, meaning that $600 \mu \mathrm{g}$ retinol/d or $1200 \mu \mathrm{g} \beta$-carotene/d corrected dark adaptation. This latter study was considered by the IOM to be the more reliable VEB for $\beta$-carotene dissolved in oil ${ }^{(1)}$.

Furthermore, two other studies have measured the VEB in oil with a dose-response study design by calculating the AUC for retinyl palmitate in the TRL fraction ${ }^{(63,64)}$. Both studies were designed to measure the VEB in biofortified maize porridge and biofortified cassava porridge. Also, the VEB of the reference dose of $\beta$-carotene in oil was measured, resulting in $2 \cdot 3: 1$ and $2 \cdot 1: 1$. However, although these results were obtained from a small group of subjects, they confirm the IOM recommendation of 2:1 for VEB in $\mathrm{oil}^{(1)}$.

The fourteen reported VEB measured with labelled $\beta$-carotene in oil, presented in Table 2 , have a wide range from $2 \cdot 0: 1^{(54)}$ (healthy children) to $55: 1^{(65)}$ (in one female adult after a pharmaceutical dose of $126 \mathrm{mg} \beta$-carotene). In this latter study, a VEB of 3·8:1 was obtained after a labelled dose of $6 \mathrm{mg} \beta$-carotene given to the same female subject over $21 \mathrm{~d}^{(65)}$. In another study in one male adult, the VEB was $15 \cdot 9: 1$ after a very high dose of $16 \cdot 2 \mathrm{mg} \beta$-carotene over $23 \mathrm{~d}^{(69)}$. These large variations in VEB stress the importance of carrying out experiments to measure VEB using physiological doses of $\beta$-carotene.

In four labelling studies that were performed in school children, a VEB ranging from 2·0:1 to 3·2:1 was reported. In two studies in children with adequate vitamin A status in Indonesia, low retinol diets containing daily amounts of $\left[{ }^{13} \mathrm{C}_{10}\right]$ $\beta$-carotene and $\left[{ }^{13} \mathrm{C}_{10}\right]$ retinol were consumed ${ }^{(66,67)}$. From measurements in plasma of the plateau enrichment of retinol with $\left[{ }^{13} \mathrm{C}_{10}\right]$ retinol and $\left[{ }^{13} \mathrm{C}_{5}\right]$ retinol, the VEB in oil was found on average to be $2 \cdot 4: 1$ in a 10 -week study ${ }^{(66)}$ and $2 \cdot 7: 1$ in a 3 -week study ${ }^{(67)}$. The other two studies with children were performed in China ${ }^{54,72)}$. In one study in China carried out on twenty-three healthy children over $21 \mathrm{~d}$, the VEB was quantified as $2 \cdot 0: 1^{(54)}$. The other study in China carried out over $28 \mathrm{~d}$ reported a VEB of 2.9:1 for a group of eight healthy children and a VEB of 3.2:1 for a group of eight vitamin A-deficient children ${ }^{(72)}$.

In six labelling studies that were performed in adults, VEB values ranging from 3:4:1 to $9 \cdot 1: 1$ were reported, which are less efficient than the reported VEB values for school children. Of these studies, two used a single dose of stable isotopelabelled $\left[{ }^{2} \mathrm{H}_{8}\right] \beta$-carotene in 'corn' oil with $\left[{ }^{2} \mathrm{H}_{8}\right]$ retinol as a reference dose in well-nourished adults aged 55-60 years 


\begin{tabular}{|c|c|c|c|c|c|c|c|}
\hline Reference & Food matrix & Amount ingested & $\begin{array}{l}\text { Country } \\
\text { (diet type)* }^{*}\end{array}$ & Subjects & Study design (duration) & $\begin{array}{c}\text { Result }(\mu \mathrm{g} \\
\beta \text {-carotene: } \mu \mathrm{g} \\
\text { retinol) }\end{array}$ & $\begin{array}{c}\text { SD or } \\
95 \% \mathrm{Cl}\end{array}$ \\
\hline $\begin{array}{l}\text { Hume \& } \\
\text { Krebs }^{(28)}\end{array}$ & $\beta$-Carotene in oil & $<2 \mathrm{mg} / \mathrm{d}$ & $\begin{array}{l}\text { UK (deficient } \\
\text { diet) }\end{array}$ & $\begin{array}{r}2 \text { (one for repletion with } \\
\beta \text {-carotene; } 32 \text { years) }\end{array}$ & $\begin{array}{l}\text { Depletion-repletion study } \\
\text { (14 months of depletion; } \\
6 \text { months of repletion) }\end{array}$ & $3 \cdot 8: 1$ & NA \\
\hline $\begin{array}{l}\text { Sauberlich } \\
\text { et al. }{ }^{(29)}\end{array}$ & $\beta$-Carotene in oil & $150-2400 \mu \mathrm{g} / \mathrm{d}$ & $\begin{array}{l}\text { USA (deficient } \\
\text { diet) }\end{array}$ & $\begin{array}{l}6 \text { (four for repletion with } \\
\beta \text {-carotene; } 32-43 \text { years) }\end{array}$ & $\begin{array}{l}\text { Depletion-repletion study } \\
\text { (12-25 months of depletion; } \\
1-15 \text { months of repletion) }\end{array}$ & $2 \cdot 1$ & NA \\
\hline Li et al. ${ }^{(63)}$ & $\begin{array}{l}\beta \text {-Carotene in oil added to } \\
\text { white maize porridge }\end{array}$ & $595 \mu \mathrm{g}$ (reference dose) & $\begin{array}{l}\text { USA (Western } \\
\text { diet) }\end{array}$ & 6 women (18-30 years) & $\begin{array}{l}\text { Dose-response study; AUC } \\
\text { of the TRL response }(9 \mathrm{~h})\end{array}$ & $2 \cdot 34: 1$ & $1 \cdot 61$ \\
\hline Liu et al. ${ }^{(64)}$ & $\begin{array}{l}\beta \text {-Carotene in oil added to } \\
\text { white cassava porridge }\end{array}$ & $537.6 \mu \mathrm{g}$ (reference dose) & $\begin{array}{l}\text { Colombia } \\
\text { (prudent diet) }\end{array}$ & 8 women & $\begin{array}{l}\text { Dose-response study; AUC } \\
\text { of the TRL response (9h) }\end{array}$ & $2 \cdot 11: 1$ & 0.81 \\
\hline Tang et al. ${ }^{(65)}$ & $\begin{array}{l}{\left[{ }^{2} \mathrm{H}_{8}\right] \beta-\text { Carotene capsule }} \\
\text { in 'corn' oil }\end{array}$ & $\begin{array}{c}6 \mathrm{mg} \text { (reference dose } \\
{\left[{ }^{2} \mathrm{H}_{8}\right] \text { retinyl acetate) }}\end{array}$ & $\begin{array}{l}\text { USA (Western } \\
\text { diet) }\end{array}$ & 1 women & $\begin{array}{l}\text { Single dose-response study; } \\
\quad \text { AUC }(21 \mathrm{~d})\end{array}$ & $3 \cdot 8: 1$ & NA \\
\hline Tang et al. ${ }^{(65)}$ & $\begin{array}{l}{\left[{ }^{2} \mathrm{H}_{8}\right] \beta-\text {-Carotene capsule }} \\
\text { in 'corn' oil }\end{array}$ & $126 \mathrm{mg}$ & $\begin{array}{l}\text { USA (Western } \\
\text { diet) }\end{array}$ & 1 women & $\begin{array}{l}\text { Single dose-response study; } \\
\text { AUC }(2.5 \text { years apart })\end{array}$ & $55: 1$ & NA \\
\hline $\begin{array}{l}\text { van Lieshout } \\
\quad \text { et al. }(66)\end{array}$ & $\begin{array}{l}{\left[{ }^{13} \mathrm{C}_{10}\right] \beta-\text {-Carotene in oil }} \\
\text { capsule }\end{array}$ & $\begin{array}{l}160 \mu \mathrm{g} / \mathrm{d} \text { for } 10 \text { weeks } \\
\text { (reference dose } \\
{\left[{ }^{13} \mathrm{C}_{10}\right] \text { retinol) }}\end{array}$ & $\begin{array}{l}\text { Indonesia } \\
\text { (prudent } \\
\text { diet) }\end{array}$ & $\begin{array}{l}35 \text { (nineteen boys; sixteen } \\
\text { girls) (average } 9 \text { years) }\end{array}$ & $\begin{array}{l}\text { Multiple-dose plateau study } \\
\text { with a low } \beta \text {-carotene diet } \\
\text { (10 weeks) }\end{array}$ & $2 \cdot 4: 1$ & $2 \cdot 1,2 \cdot 7$ \\
\hline $\begin{array}{l}\text { van Lieshout } \\
\quad \text { et al. }{ }^{(67)}\end{array}$ & $\begin{array}{l}{\left[{ }^{13} \mathrm{C}_{10}\right] \beta \text {-Carotene in oil }} \\
\text { capsule }\end{array}$ & $\begin{array}{l}89 \mu \mathrm{g} / \mathrm{d} \text { for } 6 \text { weeks (reference } \\
\text { dose }\left[{ }^{13} \mathrm{C}_{10}\right] \text { retinol) }\end{array}$ & $\begin{array}{l}\text { Indonesia } \\
\text { (prudent } \\
\text { diet) }\end{array}$ & $\begin{array}{l}77 \text { (thirty-nine boys; thirty- } \\
\text { eight girls) (average 9.5 } \\
\text { years) }\end{array}$ & $\begin{array}{l}\text { Multiple-dose plateau study } \\
\text { with a low } \beta \text {-carotene diet } \\
\text { (6 weeks) }\end{array}$ & $2 \cdot 7: 1$ & $2 \cdot 5,2 \cdot 8$ \\
\hline You et al. ${ }^{(68)}$ & $\begin{array}{l}\beta \text {-Carotene in refined red } \\
\text { palm oil }\end{array}$ & $\begin{array}{c}2.37 \mathrm{mg} \text { (reference dose } \\
{\left[{ }^{2} \mathrm{H}_{4}\right] \text { retinyl acetate) }}\end{array}$ & $\begin{array}{l}\text { USA (Western } \\
\text { diet) }\end{array}$ & 12 (six women, six men) & $\begin{array}{l}\text { Single-dose study; TRL } \\
\text { response }(8.5 \mathrm{~h})\end{array}$ & $5 \cdot 7: 1$ & NA \\
\hline $\begin{array}{l}\text { Hickenbottom } \\
\text { et al. }{ }^{(69)}\end{array}$ & $\begin{array}{l}{\left[{ }^{2} \mathrm{H}_{6}\right] \beta \text {-Carotene in olive }} \\
\text { oil }\end{array}$ & $\begin{array}{c}16 \cdot 2 \mathrm{mg} \text { (reference dose } \\
{\left[{ }^{2} \mathrm{H}_{6}\right] \text { retinyl acetate) }}\end{array}$ & $\begin{array}{l}\text { USA (Western } \\
\text { diet) }\end{array}$ & 1 man (36 years) & Single-dose study; AUC (23 d) & $15 \cdot 9: 1$ & NA \\
\hline Tang et al. ${ }^{(70)}$ & $\begin{array}{l}{\left[{ }^{2} \mathrm{H}_{8}\right] \beta-\text {-Carotene in 'corn' }} \\
\text { oil }\end{array}$ & $\begin{array}{l}6 \mathrm{mg} \text { (reference dose } \\
{\left[{ }^{2} \mathrm{H}_{8}\right] \text { retinyl acetate) }}\end{array}$ & $\begin{array}{l}\text { USA (Western } \\
\text { diet) }\end{array}$ & $\begin{array}{l}22 \text { (ten men; twelve women) } \\
\text { (average } 60 \text { years) }\end{array}$ & $\begin{array}{l}\text { Single dose-response study; } \\
\text { AUC (56d) }\end{array}$ & $\begin{array}{r}9 \cdot 1: 1 \text { (range } \\
2 \cdot 4-20 \cdot 2 \text { ) }\end{array}$ & $5 \cdot 8$ \\
\hline Wang et al. ${ }^{(25)}$ & $\begin{array}{l}{\left[{ }^{2} \mathrm{H}_{8}\right] \beta-\text {-Carotene in 'corn' }} \\
\quad \text { oil }\end{array}$ & $\begin{array}{l}6 \mathrm{mg} \text { (reference dose } \\
{\left[{ }^{2} \mathrm{H}_{8}\right] \text { retinyl acetate) }}\end{array}$ & $\begin{array}{l}\text { Rural China } \\
\text { (prudent } \\
\text { diet) }\end{array}$ & $\begin{array}{l}11 \text { (seven men; four women) } \\
\text { (average } 55 \text { years) }\end{array}$ & $\begin{array}{l}\text { Single dose-response study; } \\
\text { AUC }(56 \mathrm{~d})\end{array}$ & $\begin{array}{r}9 \cdot 1: 1 \text { (range } \\
3 \cdot 8-22 \cdot 8 \text { ) }\end{array}$ & $5 \cdot 3$ \\
\hline $\begin{array}{l}\text { Haskell } \\
\quad \text { et al. }\end{array}$ & $\begin{array}{l}\text { Synthetic } \beta \text {-carotene in } \\
\text { 'corn' oil capsule }\end{array}$ & $\begin{array}{l}2.25 \mathrm{mg} \text { for } 60 \mathrm{~d} \text { (reference } \\
\text { dose }\left[{ }^{2} \mathrm{H}_{4}\right] \text { retinyl acetate) }\end{array}$ & $\begin{array}{l}\text { Bangladesh } \\
\text { (prudent } \\
\text { diet) }\end{array}$ & 14 men (average 22.6 years) & $\begin{array}{l}\text { Multiple dose-response study } \\
\quad(60 \mathrm{~d})\end{array}$ & 6.3:1 & NA \\
\hline Li et al. ${ }^{(72)}$ & $\begin{array}{l}\text { Pure } \beta \text {-carotene in oil } \\
\text { capsule }\end{array}$ & $\begin{array}{l}200 \mu \mathrm{g} / \mathrm{d} \text { for } 7 \mathrm{~d} \text { (reference } \\
\text { dose }\left[{ }^{13} \mathrm{C}_{10}\right] \text { retinyl acetate) }\end{array}$ & $\begin{array}{l}\text { China (Wes- } \\
\text { tern diet) }\end{array}$ & $\begin{array}{l}8 \text { (normal vitamin A status) } \\
(7-9 \text { years })\end{array}$ & $\begin{array}{l}\text { Single dose-response study } \\
\text { (28d) }\end{array}$ & $2 \cdot 9: 1$ & NA \\
\hline Li et al. ${ }^{(72)}$ & $\begin{array}{l}\text { Pure } \beta \text {-carotene in oil } \\
\text { capsule }\end{array}$ & $\begin{array}{l}200 \mu \mathrm{g} / \mathrm{d} \text { for } 7 \mathrm{~d} \text { (reference } \\
\text { dose }\left[{ }^{13} \mathrm{C}_{10}\right] \text { retinyl acetate) }\end{array}$ & $\begin{array}{l}\text { China (Wes- } \\
\text { tern diet) }\end{array}$ & $\begin{array}{l}8 \text { (vitamin A-deficient) } \\
(7-9 \text { years })\end{array}$ & $\begin{array}{l}\text { Single dose-response study } \\
\text { (28d) }\end{array}$ & $3 \cdot 2: 1$ & NA \\
\hline $\begin{array}{l}\text { Van Loo- } \\
\text { Bouwman } \\
\text { et al. }{ }^{(73)}\end{array}$ & $\begin{array}{l}{\left[{ }^{13} \mathrm{C}_{10}\right] \beta \text {-Carotene in oil }} \\
\text { capsule }\end{array}$ & $\begin{array}{l}\text { Average } 55 \mu \mathrm{g} / \mathrm{d} \text { (reference } \\
\text { dose }\left[{ }^{13} \mathrm{C}_{10}\right] \text { retinyl palmi- } \\
\text { tate) }\end{array}$ & $\begin{array}{l}\text { The } \\
\text { Netherlands } \\
\text { (Western } \\
\text { diet) }\end{array}$ & $\begin{array}{l}24 \text { (ten men; fourteen } \\
\text { women) (average } 22 \text { years) }\end{array}$ & $\begin{array}{l}\text { Multiple-dose plateau study } \\
\text { with a controlled diet ( } 21 \mathrm{~d})\end{array}$ & $3 \cdot 4: 1$ & $2 \cdot 8,3 \cdot 9$ \\
\hline $\begin{array}{l}\text { Van Loo- } \\
\text { Bouwman } \\
\text { et al. }{ }^{(33)}\end{array}$ & $\begin{array}{l}{\left[{ }^{13} \mathrm{C}_{10}\right] \beta \text {-Carotene in oil }} \\
\text { capsule }\end{array}$ & $\begin{array}{l}\text { Average } 190 \mu \mathrm{g} / \mathrm{d} \text { (reference } \\
\text { dose }\left[{ }^{13} \mathrm{C}_{10}\right] \text { retinyl palmi- } \\
\text { tate) }\end{array}$ & $\begin{array}{l}\text { The } \\
\text { Netherlands } \\
\text { (Western } \\
\text { diet) }\end{array}$ & $\begin{array}{l}17 \text { (five men; twelve women) } \\
\text { (average } 49 \text { years) }\end{array}$ & $\begin{array}{l}\text { Multiple-dose plateau study } \\
\text { with a controlled diet ( } 14 \mathrm{~d})\end{array}$ & $3 \cdot 6: 1$ & $2 \cdot 8,4 \cdot 6$ \\
\hline Tang et al. ${ }^{(54)}$ & $\begin{array}{l}{\left[{ }^{2} \mathrm{H}_{8}\right] \beta \text {-Carotene in 'corn' }} \\
\text { oil capsule }\end{array}$ & $\begin{array}{l}0.5 \mathrm{mg} \text { (reference dose } \\
{\left[{ }^{13} \mathrm{C}_{10}\right] \text { retinyl acetate) }}\end{array}$ & $\begin{array}{l}\text { Rural China } \\
\text { (prudent } \\
\text { diet) }\end{array}$ & $\begin{array}{l}23 \text { (thirteen boys; ten girls) } \\
\text { (6-8 years) }\end{array}$ & $\begin{array}{l}\text { Single dose-response study; } \\
\text { AUC (21d) }\end{array}$ & $2 \cdot 0: 1$ & 0.9 \\
\hline
\end{tabular}


Table 3. Overview of the studies with unlabelled $\beta$-carotene in a mixed diet from multiple vegetables and fruits to quantify vitamin $A$ equivalency of $\beta$-carotene in a mixed plant diet

\begin{tabular}{|c|c|c|c|c|c|c|c|}
\hline Reference & Food matrix & Amount ingested & Country (diet type)* & Subjects & Study design (duration) & $\begin{array}{c}\text { Result ( } \mu \mathrm{g} \\
\beta \text {-carotene: } \mu \mathrm{g} \text { retinol) }\end{array}$ & SD or $95 \% \mathrm{Cl}$ \\
\hline De Pee et al. ${ }^{(11)}$ & $\begin{array}{l}\text { Orange fruits (papaya, } \\
\text { mango, squash, } \\
\text { pumpkin) }\end{array}$ & $4.3 \mathrm{mg} / \mathrm{d}$ & $\begin{array}{l}\text { Indonesia (prudent } \\
\text { diet) }\end{array}$ & $\begin{array}{l}45 \text { (twenty-five boys; } \\
\text { twenty girls) } \\
\text { (average } 11 \text { years) }\end{array}$ & $\begin{array}{l}\text { Dose-response study with } \\
\text { mainly a controlled diet } \\
\text { ( } 9 \text { weeks) }\end{array}$ & $12: 1$ & 6,29 \\
\hline De Pee et al. ${ }^{(11)}$ & $\begin{array}{l}\text { Dark-green leafy } \\
\text { vegetables (cassava } \\
\text { leaves, water spinach, } \\
\text { spinach) and carrots }\end{array}$ & $4.1 \mathrm{mg} / \mathrm{d}$ & $\begin{array}{l}\text { Indonesia (prudent } \\
\text { diet) }\end{array}$ & $\begin{array}{l}49 \text { (twenty-nine boys; } \\
\text { twenty girls) } \\
\text { (average } 11 \text { years) }\end{array}$ & $\begin{array}{l}\text { Dose-response study with } \\
\text { mainly a controlled diet } \\
\text { (9 weeks) }\end{array}$ & $26: 1$ & 3,76 \\
\hline Khan et al. ${ }^{(74)}$ & $\begin{array}{l}\text { Orange and yellow fruits } \\
\text { (e.g. papaya, mango) }\end{array}$ & $4.8 \mathrm{mg} / \mathrm{d}$ & $\begin{array}{l}\text { Vietnam (prudent } \\
\text { diet) }\end{array}$ & $\begin{array}{l}69 \text { breast-feeding } \\
\text { women (average } \\
26 \text { years) }\end{array}$ & $\begin{array}{l}\text { Dose-response study with } \\
\text { mainly a controlled diet } \\
\text { (10 weeks) }\end{array}$ & $12: 1$ & 8,22 \\
\hline Khan et al. ${ }^{(74)}$ & $\begin{array}{l}\text { Dark-green leafy } \\
\text { vegetables }\end{array}$ & $5.6 \mathrm{mg} / \mathrm{d}$ & $\begin{array}{l}\text { Vietnam (prudent } \\
\text { diet) }\end{array}$ & $\begin{array}{l}73 \text { breast-feeding } \\
\text { women (average } \\
26 \text { years) }\end{array}$ & $\begin{array}{l}\text { Dose-response study with } \\
\text { mainly a controlled diet } \\
\text { (10 weeks) }\end{array}$ & $28: 1$ & 17,84 \\
\hline Tang et al. ${ }^{(75)}$ & $\begin{array}{l}\text { Dark-green and yellow } \\
\text { vegetables }\end{array}$ & $4.7 \mathrm{mg} / \mathrm{d}$ & $\begin{array}{l}\text { Rural China } \\
\text { (prudent diet) }\end{array}$ & $\begin{array}{l}22 \text { (nine boys; } \\
\text { thirteen girls) } \\
\text { (average } 6 \text { years) }\end{array}$ & $\begin{array}{l}\text { Dose-response study with } \\
\text { mainly a controlled diet } \\
\text { (10 weeks) }\end{array}$ & 27:1 (estimated) & 19,48 \\
\hline $\begin{array}{l}\text { Van Loo-Bouwman } \\
\text { et al. }{ }^{(73)}\end{array}$ & $\begin{array}{l}\text { Mixed vegetables high in } \\
\beta \text {-carotene (carrot, } \\
\text { green peas, endive, } \\
\text { savoy cabbage, } \\
\text { broccoli) }\end{array}$ & $6.8 \mathrm{mg} / \mathrm{d}$ & $\begin{array}{r}\text { The Netherlands } \\
\text { (Western diet) }\end{array}$ & $\begin{array}{l}24 \text { (ten men; fourteen } \\
\text { women) (average } \\
22 \text { years) }\end{array}$ & $\begin{array}{l}\text { Multiple-dose plateau study } \\
\text { with a controlled diet; } \\
\text { mass balance }(21 \mathrm{~d})\end{array}$ & $\begin{array}{c}15 \cdot 7: 1 \text { ( } 10 \cdot 4: 1 \text { if exclud- } \\
\text { ing six subjects with } \\
\text { negative oral-faecal } \\
\text { mass balance) } \dagger\end{array}$ & $\begin{array}{c}1 \cdot 0,30 \cdot 4 ; 5 \cdot 3, \\
15 \cdot 5\end{array}$ \\
\hline $\begin{array}{l}\text { Van Loo-Bouwman } \\
\text { et al. }{ }^{(73)}\end{array}$ & $\begin{array}{l}\text { Supplemental } \beta \text {-carotene } \\
\text { and mixed vegetables } \\
\text { low in } \beta \text {-carotene } \\
\text { (e.g. cauliflower, white } \\
\text { cabbage) }\end{array}$ & $\begin{array}{l}3.3 \mathrm{mg} / \mathrm{d} \\
\quad \text { (supplemented); } \\
1.6 \mathrm{mg} / \mathrm{d} \\
\text { (vegetables) }\end{array}$ & $\begin{array}{l}\text { The Netherlands } \\
\text { (fortified Western } \\
\text { diet) }\end{array}$ & $\begin{array}{l}24 \text { (ten men; fourteen } \\
\text { women) (average } \\
22 \text { years) }\end{array}$ & $\begin{array}{l}\text { Multiple-dose plateau study } \\
\text { with a controlled diet; } \\
\text { mass balance }(21 \mathrm{~d})\end{array}$ & $5 \cdot 4: 1$ & $3 \cdot 8,7 \cdot 0$ \\
\hline $\begin{array}{l}\text { Van Loo-Bouwman } \\
\text { et al. }{ }^{(33)}\end{array}$ & $\begin{array}{l}\text { Mixed vegetables high in } \\
\beta \text {-carotene }\end{array}$ & $7.6 \mathrm{mg} / \mathrm{d}$ & $\begin{array}{r}\text { The Netherlands } \\
\text { (Western diet) }\end{array}$ & $\begin{array}{l}17 \text { (five men; twelve } \\
\text { women) (average } \\
49 \text { years) }\end{array}$ & $\begin{array}{l}\text { Multiple-dose plateau study } \\
\text { with a controlled diet; } \\
\text { mass balance (14 d) }\end{array}$ & $12 \cdot 5: 1$ & NA \\
\hline $\begin{array}{l}\text { Van Loo-Bouwman } \\
\text { et al. }{ }^{(33)}\end{array}$ & $\begin{array}{l}\text { Supplemental } \beta \text {-carotene } \\
\text { and mixed vegetables } \\
\text { low in } \beta \text {-carotene }\end{array}$ & $\begin{array}{l}2.6 \mathrm{mg} / \mathrm{d} \\
\quad \text { (supplemented); } \\
0.4 \mathrm{mg} / \mathrm{d} \\
\text { (vegetables) }\end{array}$ & $\begin{array}{l}\text { The Netherlands } \\
\text { (fortified Western } \\
\text { diet) }\end{array}$ & $\begin{array}{l}17 \text { (five men; twelve } \\
\text { women) (average } \\
49 \text { years) }\end{array}$ & $\begin{array}{l}\text { Multiple-dose plateau study } \\
\text { with a controlled diet; } \\
\text { mass balance (14 d) }\end{array}$ & $6 \cdot 7: 1$ & NA \\
\hline
\end{tabular}

NA, not available.

"The 'prudent' diet type is high in fresh fruits and vegetables and whole grains (e.g. rice, maize), and low in meat.

$\dagger$ Due to the relatively high weight of total $72 \mathrm{~h}$ faecal collection. 
Table 4. Overview of the studies with unlabelled or extrinsically isotope-labelled or intrinsically isotope-labelled $\beta$-carotene in a diet from a single vegetable or fruit to quantify vitamin A equivalency of $\beta$-carotene in a single vegetable or fruit

\begin{tabular}{|c|c|c|c|c|c|c|c|}
\hline Reference & Food matrix & Amount ingested & $\begin{array}{l}\text { Country } \\
\text { (diet type) }^{*}\end{array}$ & Subjects & Study design (duration) & $\begin{array}{l}\text { Result }(\mu \mathrm{g} \\
\beta \text {-carotene: } \mu \mathrm{g} \\
\text { retinol) }\end{array}$ & $\begin{array}{l}\text { SD or } \\
95 \% \mathrm{Cl}\end{array}$ \\
\hline Li et al. ${ }^{(63)}$ & Maize porridge (unlabelled) & $527 \mu \mathrm{g}$ & USA (Western diet) & $\begin{array}{l}6 \text { women }(18-30 \\
\text { years) }\end{array}$ & $\begin{array}{l}\text { Dose-response study; AUC of } \\
\text { the TRL response }(9 \mathrm{~h})\end{array}$ & $6 \cdot 48: 1$ & 3.51 \\
\hline Liu et al. ${ }^{(64)}$ & $\begin{array}{l}\beta \text {-Carotene-biofortified cassava } \\
\text { porridge (unlabelled) }\end{array}$ & $1097.5 \mu \mathrm{g}$ & $\begin{array}{l}\text { Colombia (prudent } \\
\text { diet) }\end{array}$ & 8 women & $\begin{array}{l}\text { Dose-response study; AUC of } \\
\text { the TRL response }(9 \mathrm{~h})\end{array}$ & $2 \cdot 80: 1$ & $1 \cdot 77$ \\
\hline La Frano et al. ${ }^{(76)}$ & $\begin{array}{l}\beta \text {-Carotene-biofortified cassava } \\
\text { porridge (unlabelled) }\end{array}$ & $\begin{array}{l}2 \mathrm{mg} \text { with added oil of } \\
20 \mathrm{~g}\end{array}$ & USA (Western diet) & $\begin{array}{l}12 \text { women (aver- } \\
\text { age } 29 \text { years) }\end{array}$ & $\begin{array}{l}\text { Dose-response study; AUC of } \\
\text { the TRL response }(9.5 \mathrm{~h})\end{array}$ & $4 \cdot 2: 1$ & $3 \cdot 1$ \\
\hline La Frano et al. ${ }^{(76)}$ & $\begin{array}{l}\beta \text {-Carotene-biofortified cassava } \\
\text { porridge (unlabelled) }\end{array}$ & $2 \mathrm{mg}$ without added oil & USA (Western diet) & $\begin{array}{l}12 \text { women (aver- } \\
\text { age } 29 \text { years) }\end{array}$ & $\begin{array}{l}\text { Dose-response study; AUC of } \\
\text { the TRL response }(9.5 \mathrm{~h})\end{array}$ & $4 \cdot 5: 1$ & $3 \cdot 1$ \\
\hline Parker et al. ${ }^{(39)}$ & $\begin{array}{l}\text { Raw carrot (extrinsically } \\
\text { isotope-labelled) }\end{array}$ & $\begin{array}{l}5.25 \mathrm{mg} \text { (reference } \\
\text { dose }\left[{ }^{2} \mathrm{H}_{4}\right] \text { retinyl } \\
\text { acetate) }\end{array}$ & $\begin{array}{l}\text { USA (one undefined } \\
\text { meal) }\end{array}$ & 1 & $\begin{array}{l}\text { Dose-response study; AUC } \\
(7 \mathrm{~h})\end{array}$ & $13: 1$ & NA \\
\hline Edwards et al. ${ }^{(43)}$ & $\begin{array}{l}\text { Raw carrot or raw spinach } \\
\text { (extrinsically isotope- } \\
\text { labelled) }\end{array}$ & $\begin{array}{l}6 \mathrm{mg} \text { (reference dose } \\
{\left[{ }^{2} \mathrm{H}_{4}\right] \text { retinyl acetate) }}\end{array}$ & USA (one meal) & $\begin{array}{l}3 \text { (two men; one } \\
\text { woman) } \\
\text { (25-35 years) }\end{array}$ & $\begin{array}{l}\text { Single-dose study; TRL } \\
\quad \text { response }(8.5 \mathrm{~h})\end{array}$ & $23: 1$ & NA \\
\hline Haskell et al. ${ }^{(71)}$ & $\begin{array}{l}\text { Indian spinach (extrinsically } \\
\text { isotope-labelled) }\end{array}$ & $\begin{array}{l}4.5 \mathrm{mg} / \mathrm{d} \text { for } 60 \mathrm{~d} \\
\text { (reference dose } \\
{\left[{ }^{2} \mathrm{H}_{4}\right] \text { retinyl acetate) }}\end{array}$ & $\begin{array}{l}\text { Bangladesh (prudent } \\
\text { diet) }\end{array}$ & $\begin{array}{l}14 \text { men (average } \\
22.6 \text { years) }\end{array}$ & $\begin{array}{l}\text { Multiple dose-response study } \\
\quad(60 \mathrm{~d})\end{array}$ & $9 \cdot 5: 1$ & NA \\
\hline Haskell et al. ${ }^{(71)}$ & $\begin{array}{l}\text { Sweet potato (extrinsically } \\
\text { isotope-labelled) }\end{array}$ & $4.5 \mathrm{mg} / \mathrm{d}$ & $\begin{array}{l}\text { Bangladesh (prudent } \\
\text { diet) }\end{array}$ & $\begin{array}{l}14 \text { men (average } \\
22.6 \text { years) }\end{array}$ & $\begin{array}{l}\text { Multiple dose-response study } \\
\text { (60 d) }\end{array}$ & $13 \cdot 4: 1$ & NA \\
\hline Tang et al. ${ }^{(57)}$ & $\begin{array}{l}\text { Spinach }\left[{ }^{2} \mathrm{H}_{10}\right] \beta \text {-carotene } \\
\quad \text { (intrinsically isotope-labelled) }\end{array}$ & $\begin{array}{l}11 \mathrm{mg} \text { (reference dose } \\
{\left[{ }^{13} \mathrm{C}_{8}\right] \text { retinyl acetate) }}\end{array}$ & USA (Western diet) & $\begin{array}{l}14 \text { (seven men; } \\
\text { seven women) } \\
\text { (average } 57 \\
\text { years) }\end{array}$ & $\begin{array}{l}\text { Single dose-response study; } \\
\text { AUC ( } 36 \mathrm{~d})\end{array}$ & $\begin{array}{r}20 \cdot 9: 1 \text { (range } \\
10 \cdot 0-46 \cdot 5 \text { ) }\end{array}$ & $9 \cdot 0$ \\
\hline Tang et al. ${ }^{(57)}$ & $\begin{array}{l}\text { Carrot }\left[{ }^{2} \mathrm{H}_{10}\right] \beta \text {-carotene } \\
\quad \text { (intrinsically isotope-labelled) }\end{array}$ & $11 \mathrm{mg}$ & USA (Western diet) & $\begin{array}{l}7 \text { women (aver- } \\
\text { age } 56 \text { years) }\end{array}$ & $\begin{array}{l}\text { Single dose-response study; } \\
\text { AUC ( } 36 \mathrm{~d})\end{array}$ & $\begin{array}{c}14.8: 1 \text { (range } \\
7 \cdot 7-24 \cdot 5 \text { ) }\end{array}$ & $6 \cdot 5$ \\
\hline Wang et al. ${ }^{(77)}$ & $\begin{array}{l}\text { Spinach }\left[{ }^{2} \mathrm{H}_{10}\right] \beta \text {-carotene } \\
\quad \text { (intrinsically isotope-labelled) }\end{array}$ & $\begin{array}{c}12 \mathrm{mg} \text { (reference dose } \\
\left.{ }^{13} \mathrm{C}_{10}\right] \text { retinyl acetate) }\end{array}$ & China (Western diet) & $\begin{array}{l}10 \text { men } \\
\quad(43-56 \text { years })\end{array}$ & $\begin{array}{l}\text { Single dose-response study; } \\
\text { AUC (56 d) }\end{array}$ & $9 \cdot 0: 1$ & 4.5 \\
\hline Li et al. ${ }^{(72)}$ & $\begin{array}{l}\text { Spinach }\left[{ }^{2} \mathrm{H}_{10}\right] \beta \text {-carotene } \\
\quad \text { (intrinsically isotope-labelled) }\end{array}$ & $\begin{array}{l}230 \mu \mathrm{g} / \mathrm{d} \text { for } 7 \mathrm{~d} \\
\text { (reference dose } \\
{\left[{ }^{13} \mathrm{C}_{10}\right] \text { retinyl acetate) }}\end{array}$ & China (Western diet) & $\begin{array}{l}8 \text { (normal vitamin } \\
\text { A status) } \\
\text { (7-9 years) }\end{array}$ & $\begin{array}{l}\text { Single dose-response study } \\
\quad(28 \mathrm{~d})\end{array}$ & $10 \cdot 1: 1$ & NA \\
\hline Li et al. ${ }^{(72)}$ & $\begin{array}{l}\text { Spinach }\left[{ }^{2} \mathrm{H}_{10}\right] \beta \text {-carotene } \\
\quad \text { (intrinsically isotope-labelled) }\end{array}$ & $\begin{array}{l}230 \mu \mathrm{g} / \mathrm{d} \text { for } 7 \mathrm{~d} \\
\text { (reference dose } \\
{\left[{ }^{13} \mathrm{C}_{10}\right] \text { retinyl acetate) }}\end{array}$ & China (Western diet) & $\begin{array}{l}8 \text { (vitamin A- } \\
\text { deficient) } \\
\text { (7-9 years) }\end{array}$ & $\begin{array}{l}\text { Single dose-response study } \\
\text { (28d) }\end{array}$ & 10.3:1 & NA \\
\hline Tang et al. ${ }^{(55)}$ & $\begin{array}{l}\text { Golden Rice }\left[{ }^{2} \mathrm{H}_{10}\right] \beta \text {-carotene } \\
\text { with butter (intrinsically } \\
\text { isotope-labelled) }\end{array}$ & $\begin{array}{l}0.99-1.53 \mathrm{mg} \\
\text { (reference dose } \\
{\left[{ }^{13} \mathrm{C}_{10}\right] \text { retinyl acetate) }}\end{array}$ & USA (Western diet) & $\begin{array}{l}5 \text { (two men; } \\
\text { three women) } \\
\text { (41-70 years) }\end{array}$ & $\begin{array}{l}\text { Single dose-response study; } \\
\text { AUC ( } 36 \mathrm{~d})\end{array}$ & $\begin{array}{c}3.8: 1 \text { (range } \\
1.6-6.4 \text { ) }\end{array}$ & $1 \cdot 7$ \\
\hline Muzhingi et al. ${ }^{(53)}$ & $\begin{array}{l}\text { Yellow maize }\left[{ }^{2} \mathrm{H}_{9}\right] \mathrm{\beta}- \\
\text { carotene porridge with butter } \\
\text { (intrinsically isotope-labelled) }\end{array}$ & $\begin{array}{l}1.2 \mathrm{mg} \text { (reference dose } \\
{\left[{ }^{13} \mathrm{C}_{10}\right] \text { retinyl acetate) }}\end{array}$ & $\begin{array}{l}\text { Zimbabwe (prudent } \\
\text { diet) }\end{array}$ & $\begin{array}{l}8 \text { men (average } \\
48 \text { years) }\end{array}$ & $\begin{array}{l}\text { Single dose-response study; } \\
\text { AUC ( } 36 \mathrm{~d})\end{array}$ & $\begin{array}{c}3.2: 1 \text { (range } \\
1.5-5 \cdot 3 \text { ) }\end{array}$ & 1.5 \\
\hline Ghavami et al. ${ }^{(56)}$ & $\begin{array}{l}\text { Stir-fried carrot }\left[{ }^{2} \mathrm{H}_{10}\right] \mathrm{\beta}- \\
\text { carotene in groundnut oil } \\
\text { (intrinsically isotope-labelled) }\end{array}$ & $\begin{array}{l}\text { 3.79 mg (reference } \\
\text { doses } \\
{\left[{ }^{13} \mathrm{C}_{20}\right] \beta \text {-carotene }} \\
\text { and }\left[{ }^{2} \mathrm{H}_{4}\right] \text { retinyl } \\
\text { acetate) }\end{array}$ & UK (Western diet) & $\begin{array}{l}4 \text { (two men; two } \\
\text { women) } \\
\text { (average } 45 \\
\text { years) }\end{array}$ & $\begin{array}{l}\text { Single dose-response study; } \\
\text { AUC (72h) }\end{array}$ & $11 \cdot 6: 1$ & NA \\
\hline Ghavami et al. ${ }^{(56)}$ & $\begin{array}{l}\text { Raw carrot }\left[{ }^{2} \mathrm{H}_{10]}\right] \beta \text {-carotene } \\
\quad \text { (intrinsically isotope-labelled) }\end{array}$ & $\begin{array}{l}\text { 3.79 mg (reference } \\
\text { doses } \\
{\left[{ }^{13} \mathrm{C}_{20}\right] \beta \text {-carotene }} \\
\text { and }\left[{ }^{2} \mathrm{H}_{4}\right] \text { retinyl } \\
\text { acetate) }\end{array}$ & UK (Western diet) & $\begin{array}{l}4 \text { (two men; two } \\
\text { women) } \\
\text { (average } 45 \\
\text { years) }\end{array}$ & $\begin{array}{l}\text { Single dose-response study; } \\
\text { AUC }(72 \mathrm{~h})\end{array}$ & $77: 1$ & NA \\
\hline
\end{tabular}


over $56 \mathrm{~d}$ with a low $\beta$-carotene $\operatorname{diet}^{(70,25)}$. The average VEB was 9.1:1 in twenty-two adults in the $\mathrm{USA}^{(70)}$ and $9 \cdot 1: 1$ in eleven rural Chinese adults with a diet of limited amounts of animal foods ${ }^{(25)}$. Haskell et al. ${ }^{(71)}$ reported an estimated VEB in oil of 6.3:1 for synthetic $\beta$-carotene in fourteen young men in Bangladesh. In one short-term study, the VEB was quantified to be $5 \cdot 7: 1$ in red palm oil after $8.5 \mathrm{~h}$ of a $\left[{ }^{2} \mathrm{H}_{8}\right]$ retinyl acetate dose administered to twelve adults ${ }^{(68)}$. In two dietcontrolled studies conducted in The Netherlands, a VEB of 3.4:1 was quantified in twenty-four healthy young adults ${ }^{(73)}$ and a VEB of 3.6:1 in seventeen ileostomy subjects ${ }^{(33)}$ using the same dual-isotope dilution technique as used by van Lieshout $e$ t al. ${ }^{(66,67)}$.

In conclusion, at low physiological doses, a VEB in oil of approximately 3:1 was obtained; however, at very high doses, the VEB decreases, as already mentioned in the introduction.

\section{Vegetable matrix: $\beta$-carotene in a diet with multiple vegetables and fruits}

Table 3 presents five diet-controlled studies with a duration of 2 to 10 weeks with multiple vegetables and fruits. The study design of the study in school children in Indonesia ${ }^{(11)}$ and of the study in breast-feeding women in Vietnam ${ }^{(74)}$ were similar and comprised four dietary groups: low-retinol, lowcarotenoid (negative control); dark-green leafy vegetables (also carrots in the Indonesian study); yellow and orange fruits; a retinol-containing diet (positive control). The increase in serum retinol concentrations was measured over the 9 to 10 weeks, mainly the diet-controlled period. For the dark-green leafy vegetables, the VEB was estimated to be $26: 1$ in the Indonesian study ${ }^{(11)}$ and 28:1 in the Vietnamese study ${ }^{(74)}$, while for the fruits, it was 12:1 in both studies. In an intervention study in Chinese kindergarten school children, a VEB of 27:1 was calculated for a diet with green and yellow vegetables ${ }^{(75)}$. In two completely diet-controlled studies in The Netherlands with a diet containing $\beta$-carotene-rich vegetables, a VEB of $15 \cdot 7: 1$ was obtained in twenty-four healthy young adults ${ }^{(73)}$ and a VEB of 12.5:1 in seventeen ileostomy subjects ${ }^{(33)}$. The same two studies crossed-over with another controlled diet for 2 to 3 weeks. That diet contained $\beta$-carotene-poor vegetables and fruits with consumption of food items fortified with $\beta$-carotene and/or $\beta$-carotene supplements, such as those regularly consumed in industrialised societies. For this complex $\beta$-carotene supplemented and vegetable matrix, the VEB was found to be $5 \cdot 4: 1^{(73)}$ and $6 \cdot 7: 1^{(33)}$.

In conclusion, the seven reported VEB for a diet with multiple vegetables are lower than the IOM recommendation of 12:1 for VEB in a mixed plant diet. For the fruit matrix, the VEB of 12:1 is realistic.

\section{Vegetable matrix: $\beta$-carotene in a single vegetable or fruit matrix}

Of the thirteen studies presented in Table 4, three were performed with a single unlabelled vegetable by measuring the TRL response over $9 \mathrm{~h}$ in women. A study with maize 
porridge determined a VEB of $6 \cdot 48: 1^{(63)}$. A study with biofortified cassava porridge in Colombia reported a VEB of $2 \cdot 80: 1^{(64)}$. Another study with biofortified cassava porridge in the USA determined a VEB of $4 \cdot 2: 1$ when provided with added oil and a VEB of 4.5:1 when provided without added oil $^{(76)}$.

Overall, three $\beta$-carotene-labelled studies, which used $\left[{ }^{2} \mathrm{H}_{4}\right]$ retinyl acetate as the reference dose, are presented in Table 4 . Parker et $a l .{ }^{(39)}$ reported a VEB of 13:1 for raw carrot in one adult. Edwards et al. ${ }^{(43)}$ estimated a VEB of 23:1 for raw carrot as well as raw spinach in three adults. A study with daily supplementation of Indian spinach and sweet potato in fourteen Bangladeshi men for $60 \mathrm{~d}$ quantified VEB values of 9.5:1 and 13.4:1, respectively ${ }^{(71)}$.

In total, seven studies have been published, which quantified the VEB for intrinsically labelled spinach, carrot, maize or Golden Rice (see Table 4). Tang et al. ${ }^{(57)}$ produced two ${ }^{2} \mathrm{H}$-labelled vegetables and quantified a VEB of 21:1 for spinach and a VEB of 15:1 for carrot over $36 \mathrm{~d}$ compared with $\left[{ }^{13} \mathrm{C}_{8}\right]$ retinyl acetate as the reference dose. In two Chinese studies with ${ }^{2} \mathrm{H}_{10}$-labelled spinach, a VEB of 9.0:1 was presented for male adults ${ }^{(77)}, 10 \cdot 1: 1$ for healthy school children and 10.3:1 for vitamin A-deficient school children ${ }^{(72)}$. A $72 \mathrm{~h}$ short-term study in the UK in four adults provided an approximate VEB of 77:1 for raw carrot and a VEB of 11.6:1 for the same intrinsically isotope-labelled carrot, but consumed after stir-frying in groundnut oil ${ }^{(56)}$. Muzhingi et al. ${ }^{(53)}$ produced ${ }^{2} \mathrm{H}$-labelled yellow maize $\beta$-carotene and determined a VEB of $3 \cdot 2: 1$ in eight men. In two studies by Tang et al. ${ }^{(54,55)}$, different measured VEB have been reported using intrinsically labelled Golden Rice with high levels of $\beta$-carotene that could be explained by the target group and duration of measuring the AUC. The first study ${ }^{(55)}$ determined a VEB of $3 \cdot 8: 1$ in five adults in the USA measured over $36 \mathrm{~d}$ and the second study ${ }^{(54)}$ obtained a VEB of 2:3:1 for twenty-three healthy children in China measured over $21 \mathrm{~d}$. The latter study in twenty-two other healthy Chinese children, a VEB of 7.5:1 was reported for intrinsically labelled spinach $^{(54)}$.

In conclusion, the type of the vegetable matrix plays a dominant role in determining the VEB as demonstrated by the VEB reported above. The intrinsic labelling method is very helpful to quantify the values of major vegetables consumed, but it is very time-consuming and expensive and will not directly quantify a value for a mixed vegetable diet.

\section{Discussion}

\section{Discussing the methods}

In summary, dose-response methods cannot discriminate between absorbed and endogenous $\beta$-carotene, while the isotopic labelling methods can discriminate between absorbed and endogenic $\beta$-carotene. In small physiological doses, isotopically labelled $\beta$-carotene is measurable in blood. Intrinsic isotopic labelling methods provide reliable data on VEB in various plant sources of $\beta$-carotene. Stable isotope labelling methods measure the proportion of $\beta$-carotene ingested, which is absorbed and converted into vitamin A, but cannot distinguish between the degree of absorption and the degree of conversion. There are methods to measure VEB directly without steps in between. Therefore, in many studies, the absorption of $\beta$-carotene from various food matrices is compared with $\beta$-carotene in oil. Depletion-repletion studies can provide the VEB dissolved in oil.

In conclusion, as much data as possible should be collected to identify the impact of the three main factors that influence VEB in healthy human subjects: the amount ingested; the habitual diet type; the food matrix in which $\beta$-carotene is incorporated. Furthermore, the known polymorphisms in the BCMO1 gene ${ }^{(21,22)}$ should be measured in the participants for clarification of possible variations in estimates for VEB. Stable isotope labelling studies appear to be the best approach to collect data for large groups (healthy or specific disease) by collection of blood samples after a controlled meal or diet. Validation studies of stable isotope labelling methods are necessary to estimate and understand the reproducibility of data.

Next, we suggest the most appropriate VEB for a Western diet and a 'prudent' diet based on current evidence.

\section{Applicability of vitamin A equivalency of $\beta$-carotene in an oil matrix for a Western diet and for a 'prudent' diet}

The current recommendation of the FAO/WHO is 3.3:1 and that of the IOM is 2:1 for VEB in oil. Fortified foods and dietary supplements are available, which contain physiological doses of $\beta$-carotene in oil ${ }^{(2,4)}$ to complete an inadequate diet pattern. In four studies with unlabelled $\beta$-carotene, the IOM recommendation of 2:1 for VEB in oil has been confirmed ${ }^{(28,29,63,64)}$. In seven studies with labelled compounds, a VEB in oil ranging from 3.4:1 to 9·1:1 has been reported in adults, which was less efficient than that reported by the four studies for VEB in oil of $2 \cdot 0: 1$ to $3 \cdot 2: 1$ in school children. As has already been established ${ }^{(12,65)}$, the studies using higher amounts of ingested $\beta$-carotene resulted in higher reported VEB. By only considering the studies with amounts of ingested $\beta$-carotene that were lower than $6 \mathrm{mg}$, a VEB in oil for a Western diet ranged from $2 \cdot 3: 1$ to $5 \cdot 7: 1$ and for a 'prudent' diet from 2:1 to $6 \cdot 3: 1$. Furthermore, by only considering the studies with amounts of ingested $\beta$-carotene that were lower than $2 \mathrm{mg}$, a VEB in oil for a Western diet ranged from $2 \cdot 3: 1$ to $3 \cdot 6: 1$ and for a 'prudent' diet from 2:1 to 3·8:1.

For humans consuming $\beta$-carotene dissolved in oil, a VEB between 2:1 and 4:1 is feasible in a Western diet as well as in a 'prudent' diet. The down-regulation mechanism of the expression of BCMO1 by high doses and genetic polymorphisms in the BCMO1 gene might explain the observed variations in VEB in oil.

\section{Applicability of vitamin A equivalency of $\beta$-carotene in the plant matrix for a Western diet and for a 'prudent' diet}

The current recommendation of the FAO/WHO is 6:1 and that of the IOM is 12:1 for VEB in a mixed diet. Only five studies directly investigated the mixed plant matrix with multiple vegetables, of which three studies reported a VEB of $26: 1^{(11)}$, $27: 1^{(75)}$ and $28: 1^{(74)}$ using a 'prudent' diet, and two studies 
reported a VEB of $15 \cdot 7: 1^{(73)}$ and $12 \cdot 5: 1^{(33)}$ using a Western diet. These three studies were performed in developing countries in children ${ }^{(11,75)}$ and breast-feeding women ${ }^{(74)}$, where the subjects may have different health status and nutritional needs from those of healthy adults participating in the two studies with the Western $\operatorname{diet}^{(33,73)}$.

To determine which VEB should be used for humans in general good health, all studies with single vegetables and single fruits were considered. Only two studies investigated the fruit matrix and both reported a VEB of $12: 1^{(11,74)}$. In two studies using a fortified Western diet a VEB of $5 \cdot 4: 1$ and $6 \cdot 7: 1$ was obtained, respectively ${ }^{(33,73)}$. The results of the latter two studies reflect a combination of VEB in oil and VEB in a mixed plant matrix.

The overall VEB of approximately 9:1 for spinach (range $7 \cdot 5: 1-10 \cdot 3: 1)$ is assumed on the basis of four studies ${ }^{(52,69,70,74)}$, and excludes two studies with a reported VEB of $23: 1^{(43)}$ and $21: 1^{(57)}$ with non-physiological doses of 6 and $11 \mathrm{mg}$ $\beta$-carotene, respectively. The overall VEB of approximately 13:1 for carrot (range 11.6:1-14.8:1) is assumed on the basis of three studies ${ }^{(39,56,57)}$ and excludes the reported VEB of $77: 1$ in raw carrots ${ }^{(5)}$, which were very minimally processed before ingestion. Only one study was performed with sweet potato, which reported a VEB of $13: 1^{(71)}$. The overall VEB for three biofortified crops are approximately $4: 1$ for cassava $^{(64,74)}$, approximately $3: 1$ to approximately $6: 1$ for yellow maize ${ }^{(53,63)}$ and approximately $2 \cdot 5: 1$ to approximately $4: 1$ for Golden Rice $^{(54,55)}$. A $\beta$-carotene-rich alga is available as a food supplement and has a VEB that is similar to that of biofortified crops, namely $4 \cdot 5: 1^{(78)}$. Specially bred cassava, maize and Golden Rice are intended to be consumed in developing countries. Currently, spinach, carrots and sweet potato are widely available for consumption.

So, for the Western diet including a variety of fruits, leafy vegetables such as spinach, and root vegetables such as carrots and sweet potato, a VEB for a mixed diet of 9:1 to 16:1 is feasible.

For a 'prudent' diet including a variety of commonly consumed and specially bred vegetables, a VEB for a mixed diet could range from $4: 1$ to $28: 1$. These VEB values were obtained from human subjects in apparently normal health in developing countries. Data are not available on VEB in a mixed diet applicable to malnourished children or pregnant women. Furthermore, less favourable host-related factors, such as parasites and gastrointestinal infections, should be taken into account. In addition, individuals in developing countries have a diet relatively low in animal-derived foods, and their diet should contain as much as possible carotenoid-rich vegetables and fruits to maintain or gain adequate vitamin A status.

In conclusion, the proposed range for VEB in a mixed diet of 9:1 to 16:1 includes the IOM VEB of 12:1 and is realistic for a Western diet and Western conditions. For a 'prudent' diet including a variety of commonly consumed vegetables, a VEB in a mixed diet could range from 9:1 to 28:1. Large inter-individual variations in the estimates of VEB are reported, possibly due to genetic polymorphisms in the $B C M O 1$ gene and the degree of regulation of the expression of BCMO1 in response to vitamin A status.

\section{Different reported vitamin A equivalency of $\beta$-carotene in children and in adults}

A closer examination of some studies suggests that there is an indication that children can convert $\beta$-carotene into retinol more effectively than adults, as shown by a lower VEB in children than in adults. For instance, four studies used the same dual-isotope dilution technique and quantified a VEB in oil of 2·4:1 and 2·7:1 in children ${ }^{(66,67)}$ and a VEB in oil of $3 \cdot 4: 1$ and $3 \cdot 6: 1$ in adults ${ }^{(33,73)}$. Furthermore, two studies with intrinsically labelled Golden Rice used the single dose-response method and quantified a VEB of 2.3:1 in children ${ }^{(54)}$ and a VEB of 3.8:1 in adults ${ }^{(55)}$. As another example, two studies with intrinsically labelled spinach by Tang et al. ${ }^{(57)}$ used the single dose-response method and quantified a VEB of 7.5:1 in children ${ }^{(54)}$ and a VEB of 20.9:1 in adults. However, these different measured VEB values could be explained by the provided doses 1.4 and $11 \mathrm{mg}$ in children and adults, respectively. The VEB of 7.5:1 for spinach in children ${ }^{(54)}$ could also be compared with the estimated VEB of 9.5:1 for spinach in adults ${ }^{(71)}$ obtained with a multiple dose-response method with a reference dose of labelled retinyl acetate. However, other host-related factors (e.g. health status, immune status, treatment for worms and diarrhoea, BCMO1 expression) could explain the differences in VEB. However, two studies using the same method indicated that the VEB in children is not always higher than that in adults; those studies with intrinsically labelled spinach used the single dose-response method and reported a VEB of 10·1:1 in children ${ }^{(72)}$ and a VEB of 9.0:1 in adults ${ }^{(77)}$. When more studies are performed in children, more precise data will be available for determining whether there should be separate VEB values for children and adults.

\section{Future studies}

Studies with isotope-labelled $\beta$-carotene in fruits and vegetables in habitual diets, such as the Western diet, measured over a long period have not yet been performed. The intrinsic labelling method could be used to compare labelled $\beta$-carotene in plant sources with labelled $\beta$-carotene in oil in a common diet to provide an estimate of VEB in a complex mixed total diet. However, as has already been mentioned, the preparations will be very time-consuming and expensive, and a representative target group should be recruited. There is a need for more studies to be carried out in populations in developing countries as well as in Western populations to see whether and to what extent the VEB is influenced by nutritional status, age and other factors that might differ between developed and developing countries, such as genetic variability and polymorphisms in the BCMO1 gene across different ethnic groups.

Future isotopic labelling studies should be carried out to obtain more accurate and precise data for various factors influencing the VEB. Populations in developing countries should consume carotenoid-rich vegetables, which are processed whenever possible for optimal disruption of the food matrix to release $\beta$-carotene.

\section{Acknowledgements}

We thank Richard B. van Breemen for his critical review of the manuscript. 
The present review was funded by the Dutch Dairy Association. The Dutch Dairy Association had no role in the design, analysis or writing of this article.

C. A. V. L.-B. conducted the research, collected the data and wrote the manuscript. T. H. J. N. and G. S. contributed to the interpretation of the study results and the discussion. All authors read and approved the final manuscript.

The authors had no conflicts of interest.

\section{References}

1. US Institute of Medicine (2001) Vitamin A. In Dietary Reference Intakes for Vitamin A, Vitamin K, Arsenic, Boron, Chromium, Copper, Iodine, Iron, Manganese, Molybdenum, Nickel, Silicon, Vanadium, and Zinc, pp. 82-161. Washington, DC: National Academy Press.

2. Food and Agriculture Organization/World Health Organization (1988) Requirements of vitamin A, iron, folate and vitamin $\mathrm{B}_{12}$. FAO/WHO Joint Expert Consultation. FAO Food and Nutrition Series no. 23. Rome: WHO

3. Waijers PMCM \& Feskens EJM (2004) Assessment of vitamin A intake of the Dutch population. RIVM Report 350010002, pp. 1-47. Bilthoven, The Netherlands: National Institute for Public Health and the Environment.

4. World Health Organization (2004) Vitamin and Mineral Requirements in Human Nutrition. WHO/FAO Joint Expert Consultation, 2nd ed. Geneva: WHO.

5. Food and Agriculture Organization/World Health Organization (1967) Requirements of vitamin A, thiamin, riboflavin and niacin. FAO Food and Nutrition Series no. 8. Rome: FAO. WHO Technical Report Series no. 362. Geneva: WHO.

6. Blomstrand R \& Werner B (1967) Studies on the intestinal absorption of radioactive $\beta$-carotene and vitamin A in man. Conversion of $\beta$-carotene into vitamin A. Scand J Clin Lab Invest 19, 339-345.

7. Goodman DS, Huang HS \& Shiratori T (1966) Mechanism of the biosynthesis of vitamin A from $\beta$-carotene. $J$ Biol Chem 241, 1929-1932.

8. Yeum KJ \& Russell RM (2002) Carotenoid bioavailability and bioconversion. Annu Rev Nutr 22, 483-504.

9. van Het Hof KH, West CE, Weststrate JA, et al. (2000) Dietary factors that affect the bioavailability of carotenoids. $J$ Nutr 130, 503-506.

10. Castenmiller JJ, West CE, Linssen JP, et al. (1999) The food matrix of spinach is a limiting factor in determining the bioavailability of $\beta$-carotene and to a lesser extent of lutein in humans. J Nutr 129, 349-355.

11. De Pee S, West CE, Permaesih D, et al. (1998) Orange fruit is more effective than are dark-green leafy vegetables in increasing serum concentrations of retinol and $\beta$-carotene in schoolchildren in Indonesia. Am J Clin Nutr $\mathbf{6 8}$, 1058-1067.

12. Novotny JA, Harrison DJ, Pawlosky R, et al. (2010) $\beta$-Carotene conversion to vitamin A decreases as the dietary dose increases in humans. J Nutr 140, 915-918.

13. West CE \& Castenmiller JJ (1998) Quantification of the 'SLAMENGHI' factors for carotenoid bioavailability and bioconversion. Int J Vitam Nutr Res 68, 371-377.

14. van Het Hof KH, Brouwer IA, West CE, et al. (1999) Bioavailability of lutein from vegetables is five times higher than that of $\beta$-carotene. Am J Clin Nutr 70, 261-268.

15. Van den Berg H \& Van Vliet T (1998) Effect of simultaneous, single oral doses of $\beta$-carotene with lutein or lycopene on the $\beta$-carotene and retinyl ester responses in the triacylglycerolrich lipoprotein fraction of men. Am J Clin Nutr 68, 82-89.
16. Roodenburg AJC, Leenen R, van Het Hof KH, et al. (2000) Amount of fat in the diet affects bioavailability of lutein esters but not of $\alpha$-carotene, $\beta$-carotene, and vitamin $\mathrm{E}$ in humans. Am J Clin Nutr 71, 1187-1193.

17. Hoffmann J, Linseisen J, Riedl J, et al. (1999) Dietary fiber reduces the antioxidative effect of a carotenoid and $\alpha$-tocopherol mixture on LDL oxidation ex vivo in humans. Eur J Nutr 38, 278-285.

18. World Health Organization (2002) Prevention and control of schistosomiasis and soil-transmitted helminthiasis. Technical Report Series 912. Geneva: WHO

19. Jalal F, Nesheim MC, Agus Z, et al. (1998) Serum retinol concentrations in children are affected by food sources of $\beta$-carotene, fat intake, and anthelmintic drug. Am J Clin Nutr 68, 623-629.

20. Hesham MS, Edariah AB \& Norhayati M (2004) Intestinal parasitic infections and micronutrient deficiency: a review. Med J Malaysia 59, 284-293.

21. Leung WC, Hessel S, Meplan C, et al. (2009) Two common single nucleotide polymorphisms in the gene encoding $\beta$-carotene $15,15^{\prime}$-monoxygenase alter $\beta$-carotene metabolism in female volunteers. FASEB J 23, 1041-1053.

22. Lietz G, Oxley A, Leung W, et al. (2012) Single nucleotide polymorphisms upstream from the $\beta$-carotene $15,15^{\prime}$-monoxygenase gene influence provitamin A conversion efficiency in female volunteers. $J$ Nutr 142, 161S-165S.

23. Lin Y, Dueker SR, Burri BJ, et al. (2000) Variability of the conversion of $\beta$-carotene to vitamin $A$ in women measured by using a double-tracer study design. Am J Clin Nutr $\mathbf{7 1}$, 1545-1554.

24. Hickenbottom SJ, Follett JR, Lin Y, et al. (2002) Variability in conversion of $\beta$-carotene to vitamin $\mathrm{A}$ in men as measured by using a double-tracer study design. Am J Clin Nutr $\mathbf{7 5}$, 900-907.

25. Wang Z, Yin S, Zhao X, et al. (2004) $\beta$-Carotene-vitamin A equivalence in Chinese adults assessed by an isotope dilution technique. Br J Nutr 91, 121-131.

26. Fung TT, Willett WC, Stampfer MJ, et al. (2001) Dietary patterns and the risk of coronary heart disease in women. Arch Intern Med 161, 1857-1862.

27. Hu FB, Rimm E, Smith-Warner SA, et al. (1999) Reproducibility and validity of dietary patterns assessed with a food-frequency questionnaire. Am J Clin Nutr 69, 243-249.

28. Hume EM \& Krebs HA (1949) Vitamin A requirements of human adults; an experimental of vitamin A deprivation in men. Medical Research Council Special Report. no. 264. London: His Majesty's Stationery Office.

29. Sauberlich HE, Hodges RE, Wallace DL, et al. (1974) Vitamin A metabolism and requirements in the human studied with the use of labeled retinol. Vitam Horm 32, 251-275.

30. Lee CM, Boileau AC, Boileau TWM, et al. (1999) Review of animal models in carotenoid research. J Nutr 129, $2271-2277$.

31. Van Vliet $\mathrm{T}$ (1996) Absorption of $\beta$-carotene and other carotenoids in humans and animal models. Eur J Clin Nutr 50, S32-S37.

32. Krinsky NI, Mathews-Roth MM \& Welankiwar S (1990) The metabolism of $\left[{ }^{14} \mathrm{C}\right] \beta$-carotene and the presence of other carotenoids in rats and monkeys. J Nutr 120, 81-87.

33. Van Loo-Bouwman CA, Naber THJ, van Breemen RB, et al. (2010) Vitamin A equivalency and apparent absorption of $\beta$-carotene in ileostomy subjects using a dual-isotope dilution technique. Br J Nutr 103, 1836-1843.

34. Agte V, Jahagirdar M \& Chiplonkar S (2005) Apparent absorption of eight micronutrients and phytic acid from vegetarian meals in ileostomized human volunteers. Nutrition 21, 678-685. 
35. Faulks RM \& Southon S (2005) Challenges to understanding and measuring carotenoid bioavailability. Biochim Biophys Acta 1740, 95-100.

36. Faulks RM, Hart DJ, Brett GM, et al. (2004) Kinetics of gastrointestinal transit and carotenoid absorption and disposal in ileostomy volunteers fed spinach meals. Eur J Nutr 43, $15-22$.

37. Livny O, Reifen R, Levy I, et al. (2003) $\beta$-Carotene bioavailability from differently processed carrot meals in human ileostomy volunteers. Eur J Nutr 42, 338-345.

38. Swanson JE, Wang YY, Goodman KJ, et al. (1996) Experimental approaches to the study of $\beta$-carotene metabolism: potential of a ${ }^{13} \mathrm{C}$ tracer approach to modeling $\beta$-carotene kinetics in humans. Adv Food Nutr Res 40, 55-79.

39. Parker RS, Swanson JE, You CS, et al. (1999) Bioavailability of carotenoids in human subjects. Proc Nutr Soc 58, $155-162$.

40. O'Neill ME \& Thurnham DI (1998) Intestinal absorption of $\beta$-carotene, lycopene and lutein in men and women following a standard meal: response curves in the triacylglycerol-rich lipoprotein fraction. Br J Nutr 79, 149-159.

41. Van Vliet T, Schreurs WHP \& Van den Berg H (1995) Intestinal $\beta$-carotene absorption and cleavage in men: response of $\beta$-carotene and retinyl esters in the triglyceride-rich lipoprotein fraction after a single oral dose of $\beta$-carotene. $A m J$ Clin Nutr 62, 110-116.

42. Johnson EJ \& Russell RM (1992) Distribution of orally administered $\beta$-carotene among lipoproteins in healthy men. Am J Clin Nutr 56, 128-135.

43. Edwards AJ, You CS, Swanson JE, et al. (2001) A novel extrinsic reference method for assessing the vitamin A value of plant foods. Am J Clin Nutr 74, 348-355.

44. Edwards AJ, Nguyen CH, You CS, et al. (2002) $\alpha$-and $\beta$-Carotene from a commercial carrot puree are more bioavailable to humans than from boiled-mashed carrots, as determined using an extrinsic stable isotope reference method. $J$ Nutr 132, 159-167.

45. van Lieshout $M$, West CE \& van Breemen RB (2003) Isotopic tracer techniques for studying the bioavailability and bioefficacy of dietary carotenoids, particularly $\beta$-carotene, in humans: a review. Am J Clin Nutr 77, 12-28.

46. Dueker SR, Lin Y, Buchholz BA, et al. (2000) Long-term kinetic study of $\beta$-carotene, using accelerator mass spectrometry in an adult volunteer. J Lipid Res 41, 1790-1800.

47. Ho CC, de Moura FF, Kim SH, et al. (2009) A minute dose of ${ }^{14} \mathrm{C}-\beta$-carotene is absorbed and converted to retinoids in humans. J Nutr 139, 1480-1486.

48. Furr HC, Green MH, Haskell M, et al. (2005) Stable isotope dilution techniques for assessing vitamin A status and bioefficacy of provitamin A carotenoids in humans. Public Health Nutr 8, 596-607.

49. Parker RS, Swanson JE, Marmor D, et al. (1993) Study of $\beta$-carotene metabolism in humans using ${ }^{13} \mathrm{C}-\beta$-carotene and high precision isotope ratio mass spectrometry. Ann NY Acad Sci 691, 86-95.

50. Dueker SR, Jones AD, Smith GM, et al. (1994) Stable isotope methods for the study of $\beta$-carotene-d8 metabolism in humans utilizing tandem mass spectrometry and highperformance liquid chromatography. Anal Chem 66, $4177-4185$.

51. Novotny JA, Dueker SR, Zech LA, et al. (1995) Compartmental analysis of the dynamics of $\beta$-carotene metabolism in an adult volunteer. J Lipid Res 36, 1825-1838.

52. Grusak MA (1997) Intrinsic stable isotope labeling of plants for nutritional investigations in humans. J Nutr Biochem $\mathbf{8}$, $164-171$.
53. Muzhingi T, Gadaga TH, Siwela AH, et al. (2011) Yellow maize with high $\beta$-carotene is an effective source of vitamin A in healthy Zimbabwean men. Am J Clin Nutr 94, 510-519.

54. Tang G, Hu Y, Yin S, et al. (2012) $\beta$-Carotene in Golden Rice is as good as $\beta$-carotene in oil at providing vitamin A to children. Am J Clin Nutr 96, 658-664.

55. Tang G, Qin J, Dolnikowski GG, et al. (2009) Golden Rice is an effective source of vitamin A. Am J Clin Nutr $\mathbf{8 9}$, $1776-1783$.

56. Ghavami A, Coward WA \& Bluck LJC (2012) The effect of food preparation on the bioavailability of carotenoids from carrots using intrinsic labeling. Br J Nutr 107, 1350-1366.

57. Tang G, Qin J, Dolnikowski GG, et al. (2005) Spinach or carrots can supply significant amounts of vitamin A as assessed by feeding with intrinsically deuterated vegetables. Am J Clin Nutr 82, 821-828.

58. Putzbach K, Krucker M, Albert K, et al. (2005) Structure determination of partially deuterated carotenoids from intrinsically labeled vegetables by HPLC-MS and ${ }^{1} \mathrm{H}$ NMR. J Agric Food Chem 53, 671-677.

59. Lienau A, Glaser T, Tang G, et al. (2003) Bioavailability of lutein in humans from intrinsically labeled vegetables determined by LC-APCI-MS. J Nutr Biochem 11, 663-670.

60. Novotny JA, Kurilich AC, Britz SJ, et al. (2005) Plasma appearance of labeled $\beta$-carotene, lutein, and retinol in humans after consumption of isotopically labeled kale. J Lipid Res 46, 1896-1903.

61. Kurilich AC, Britz SJ, Clevidence BA, et al. (2003) Isotopic labeling and LC-APCI-MS quantification for investigating absorption of carotenoids and phylloquinone from kale (Brassica oleracea). J Agric Food Chem 51, 4877-4883.

62. Tang G, Ferreira AL, Grusak MA, et al. (2005) Bioavailability of synthetic and biosynthetic deuterated lycopene in humans. J Nutr Biochem 16, 229-235.

63. Li S, Nugroho A, Rochford T, et al. (2010) Vitamin A equivalence of the $\beta$-carotene in $\beta$-carotene-biofortified maize porridge consumed by women. Am J Clin Nutr 92, 1105-1112.

64. Liu W, Zhou Y, Sanchez T, et al. (2010) The vitamin A equivalence of $\beta$-carotene in $\beta$-carotene-biofortified cassava ingested by women. FASEB J 24, 92.7.

65. Tang G, Qin J, Dolnikowski GG, et al. (2000) Vitamin A equivalence of $\beta$-carotene in a woman as determined by a stable isotope reference method. Eur J Nutr 39, 7-11.

66. van Lieshout M, West CE, Muhilal, et al. (2001) Bioefficacy of $\beta$-carotene dissolved in oil studied in children in Indonesia. Am J Clin Nutr 73, 949-958.

67. van Lieshout M, West CE, Wang Y, et al. (2001) Bioavailability and bioefficacy of $\beta$-carotene measured using $\beta$-carotene and retinol, labeled with ${ }^{13} \mathrm{C}$, in Indonesian children. In Bioavailability and Bioefficacy of $\beta$-Carotene Measured Using ${ }^{13} \mathrm{C}$-Labeled $\beta$-Carotene and Retinol: Studies in Indonesian Children, pp. 49-72 [M van Lieshout, et al., editors]. $\mathrm{PhD}$ thesis. Wageningen, The Netherlands: Wageningen University.

68. You CS, Parker RS \& Swanson JE (2002) Bioavailability and vitamin A value of carotenes from red palm oil assessed by an extrinsic isotope reference method. Asia Pacific J Clin Nutr 11, S438-S442.

69. Hickenbottom SJ, Lemke SL, Dueker SR, et al. (2002) Dual isotope test for assessing $\beta$-carotene cleavage to vitamin A in humans. Eur J Nutr 41, 141-147.

70. Tang G, Qin J, Dolnikowski GG, et al. (2003) Short-term (intestinal) and long-term (postintestinal) conversion of $\beta$-carotene to retinol in adults as assessed by a stable-isotope reference method. Am J Clin Nutr 78, 259-266. 
71. Haskell MJ, Jamil KM, Hassan F, et al. (2004) Daily consumption of Indian spinach (Basella alba) or sweet potatoes has a positive effect on total-body vitamin A stores in Bangladeshi men. Am J Clin Nutr 80, 705-714.

72. Li L, Wang Y, Wu J, et al. (2007) Bioefficacy of plant carotenoid to vitamin A in school age children. Wei Sheng Yan Jiu 36 $547-551$

73. Van Loo-Bouwman CA, West CE, van Breemen RB, et al (2009) Vitamin A equivalency of $\beta$-carotene in healthy adults: limitation of the extrinsic dual-isotope dilution technique to measure matrix effect. Br J Nutr 101, 1837-1845.

74. Khan NC, West CE, de Pee S, et al. (2007) The contribution of plant foods to the vitamin A supply of lactating women in Vietnam: a randomized controlled trial. Am J Clin Nutr 85, 1112-1120.
75. Tang G, Gu X, Hu S, et al. (1999) Green and yellow vegetables can maintain body stores of vitamin $\mathrm{A}$ in Chinese children. Am J Clin Nutr 70, 1069-1076.

76. La Frano MR, Woodhouse LR, Burnett DJ, et al. (2013) Biofortified cassava increases $\beta$-carotene and vitamin A concentrations in the TAG-rich plasma layer of American women. Br J Nutr 110, 310-320.

77. Wang J, Wang Z, Wang Y, et al. (2007) Vitamin A equivalence of spinach $\beta$-carotene in human body. Wei Sheng Yan Jiu 36, 449-453.

78. Wang J, Wang Y, Wang Z, et al. (2008) Vitamin A equivalence of spirulina $\beta$-carotene in Chinese adults as assessed by using a stable-isotope reference method. Am J Clin Nutr 87, 1730-1737. 